modified his technique accordingly. He excelled at work which required the minimum amount of apparatus and the maximum amount of skill and patient observation. He endeavoured to simplify the study of the action of carcinogens on cells by employing Protozoa. The result of this project was published in "The Problem of Tumours" (1942), in which he developed the thesis that the fundamental change in the induction of malignancy occurs in the cytoplasm of cells, and results in unequal cell division. Later he suggested that "the genesis of tumours represents action on cell division, whereby the exactly equal division of essential cell constituents is so disturbed that abnormal cells are formed lacking essential constituents or having some of them in abnormal abundance". According to this hypothesis, most tumours should bo induced by carcinogenic agents when cell division is most active, and in subsequent papers he adduced evidence that this was the case.

It was characteristic of the man that when stricken down by malignant disease, of the outcome of which there was no doubt, his interests never faltered. While in hospital he continued the writing of papers he had in preparation, and he completed his last book on fishing, which he illustrated himself, within a few weeks of the end. His optimistic outlook and unquenchable enthusiasm for research were an inspiration to those who were privileged to be his friends.

$$
\text { R. J. LUDFORD. }
$$

\section{Dr. F. R. Cowper Reed}

Frederick Richard Cowper Reed was born in London on June 27, 1869, and died in Cambridge on February 8, 1946. From Harrow he went to Trinity College, Cambridge, in 1888, and was later elected a scholar. He was placed in the first class of the Natural Sciences Tripos Part 1 (1891) and Part 2 (1892), and was awarded the Harkness scholarship for geology and palæontology. In 1901 he gained the Sedgwick Prize for his work on "The Geological History of the Rivers of East Yorkshire" and in 1914 took the degree of Sc.D. Reed was appointed assistant to the Woodwardian professor of geology in 1892, and retained that post for twenty-five years, his chief duties being curatorial in the Woodwardian (later the Sedgwick) Museum. After his retirement he was able to devote himself entirely to research.

In the early years of his career, Reed did some field work and wrote on the geology of the country around Fishguard (1895) and around Waterford (1897-99); but his main work was in palæontology. He dealt with many different groups of invertebrates but was especially interested in Brachiopods and Trilobites. On British palæontology, in addition to numerous short papers dealing with faunas or with individual families or genera, he wrote two monographs for the Palæontographical Society on "The Lower Palæozoic Trilobites of Girvan" (1903-35) and on "The British Ordovician and Silurian Bellerophontacea" (1920-21). Another monograph was on the Ordovician and Silurian Brachiopoda of Girvan (Trans. Roy. Soc. Edin., 1917).

Reed did a great deal of work for the Geological Survey of India and contributed several monographs to the Paloeontologia Indica during the years 1906-44 dealing with the Palæozoic faunas of the northern and southern Shan States, of Spiti, the Central Himalayas, Yun-Nan, Kashmir, the Salt Range, Tibet, etc. He also described faunas from the Bokkeveld Beds of South Africa, the Trias and Permo-Carboniferous of
Brazil and the Ordovician of New Zealand. His paper on "Pre-Carboniferous Life Provinces" showed a philosophical outlook.

Reed made numerous journeys overseas, visiting Canada, Jamaica, South Africa, Kenya, Uganda, Cyprus, Palestine, India, Ceylon and Burma. The knowledge gained on these expeditions stood him in good stead when writing his "Geology of the British Empire" (1921).

$\mathrm{He}$ was a man of kindly nature, but so much immersed in his work that he gave the impression of leading a somewhat solitary existence.

H. Woods.

\section{Mr. A. H. D. Markwick}

SorL engineering in Great Britain has lost one of its most distinguished workers in the death on March 5, after a short illness, of Mr. A. H. D. Markwick at the early age of forty-one.

After graduating at the University of Manchester in 1924 with first-class honours in engineering, $\mathrm{Mr}$. Markwick gained his early professional experience with two firms of consulting engineers, Messrs. C. S. Allott and Son and Messrs. Kennedy and Donkin. He entered the service of the Department of Scientific and Industrial Research at the Road Research Laboratory in 1933, and took charge of the Soils Section in 1937.

Mr. Markwick was a resourceful mathematician, a good linguist, and a sound practical engineer : his most outstanding quality was, however, his power of leadership and his ability to inspire his juniors with his own energy and enthusiasm. He came to soils engineering when the importance of the soil as a factor in road design and construction was littlo appreciated by British road engineers. $\mathrm{He}$ and his colleagues speedily remedied this state of affairs by carrying out extensive researches on soil com. paction, soil stabilization and the problems involved in earth-moving and compacting machinery. This work formed the subject-matter of some twenty papers read before the Institution of Civil Engineers and other engineering bodies. The information gained proved of inestimable value during the war years, when Mr. Markwick's section was called upon to deal with many problems of aerodrome construction, the mud-crossing performance of tanks, beach-landing problems, and other special war problems concerned fundamentally with the supporting power of soil. The services of his section were also utilized by Supreme Headquarters in planning strategy and in co-ordinating the movements of armies with soil and ground conditions in the various theatres of war.

In all this work, Mr. Markwick took the leading part, and the successes achieved were largely due to his brilliance and energy. British engineering has lost a leader and his colleagues have lost a considerate and reliable friend.

T. LONSDALE.

WE regret to announce the following deaths :

Rai Bahadur Sir Upendranath Brahmachari, pro. fessor of tropical medicine, Carmichael Medical College, Calcutta, who discovered urea-stibamine and its value in treating kala-azar, on February 6, aged seventy.

Prof. Gilbert Newton Lewis, For.Mem.R.S., pro. fessor of chemistry in the University of California, aged seventy. 